\title{
The interaction of morphological changes in the liver with the development of extrahepatic manifestations in patients with chronic hepatitis C
}

\author{
Yu. Yu. Riabokon, V. A. Tumanskiy, E. V. Riabokon \\ Zaporizhzhia State Medical University, Ukraine
}

The purpose of the work was to analyze the connections of morphological changes in the liver with the manifestation of clinical signs of extrahepatic manifestations in patients with $\mathrm{CHC}$.

Material and methods. The study included 86 patients with $\mathrm{CHC}$. The correlation analysis of expressiveness degree of liver fibrosis and histological activity depending on the presence of clinical signs of extrahepatic manifestations of disease and changes of autoimmune parameters was carried out.

Results. It was found that the incidence of mixed cryoglobulins in the blood of patients with $\mathrm{CHC}$ had a dependence on the degree of fibrosis of the liver. In the presence of liver fibrosis F 3-4 mixed cryoglobulins were found in $94.2 \%$ versus $64.7 \%$ of patients with stages of liver fibrosis $F 12(P<0.01)$. In patients with stages of liver fibrosis $F 3-4$, the quantitative content of mixed cryoglobulins, RF-IgM and CIC was higher than those of patients with stages of liver fibrosis $\mathrm{F} 1-2$. In patients with fibrosis in the liver F 3-4 cryoglobulinema incidence of vasculitis with formation of Meltzer's triad was higher than in patients with liver fibrosis $\mathrm{F} 1-2(19.2 \%$ versus $2.9 \%, \mathrm{P}<0.05)$. Content of mixed cryoglobulins correlated with the degree of fibrosis of the liver $(r=+0.49, P<0.01)$. A factor $A 3$ was more often detected in patients with stage $F 3-4$, compared with patients with stage $F 1-2$ of fibrosis $(81.5 \%$ versus $19,2 \%, P<0.01)$.

Conclusions. $\mathrm{CHC}$ patients with liver fibrosis $\mathrm{F} 3-4$ are characterized with more frequent appearance of mixed cryoglobulins, higher content of RF-IgM and CIC in serum than in patients with liver fibrosis F 1-2. This explains the higher frequency of clinical manifestations of extrahepatic manifestations of immunocomplex genesis in patients with $\mathrm{F} 3-4$ fibrosis. Histological activity of $\mathrm{A} 3$ in patients with $\mathrm{CHC}$ is most often combined with fibrosis of the liver $\mathrm{F} 3-4$, which causes a high frequency of cryoglobulinemic vasculitis development in these patients.

\section{Взаємозв'язки морфологічних змін у печінці з розвитком позапечінкових проявів у хворих на хронічний гепатит С}

\section{Ю. Ю. Рябоконь, В. О. Туманський, О. В. Рябоконь}

Мета роботи - проаналізувати зв'язки морфологічних змін у печінці з маніфестацією клінічних ознак позапечінкових проявів у хворих на ХГС.

Матеріали та методи. У дослідження залучили 86 хворих на ХГС. Виконали аналіз взаємозв'язків ступеня виразності фіброзу печінки та гістологічної активності залежно від наявності клінічних ознак позапечінкових проявів захворювання та змін автоімунних параметрів.

Результати. Встановили, що частота появи змішаних кріоглобулінів у крові хворих на ХГС мала залежність від ступеня фіброзу печінки. За наявності фіброзу печінки F 3-4 змішані кріоглобуліни виявляли у 94,2 \% проти 64,7\% пацієнтів зі стадіями фіброзу печінки F 1-2 ( $<0,01)$. У хворих зі стадіями фіброзу печінки F 3-4 кількісний вміст змішаних кріоглобулінів, RF-IgM і ЦІК були вищими за аналогічні показники пацієнтів зі стадіями фіброзу печінки $F$ 1-2. У хворих із фіброзом печінки F 3-4 частота виявлення кріоглобулінемічного васкуліту з формуванням тріади Мельтцера була вища, ніж у пацієнтів із фіброзом печінки F 1-2 (19,2 \% проти 2,9%, p < 0,05). Вміст змішаних кріоглобулінів корелював зі ступенем фіброзу печінки $(r=+0,49, p<0,01)$. Активність АЗ частіше виявляли у хворих зі стадіями фіброзу печінки F 3-4 порівняно з пацієнтами, котрі мали стадії фіброзу F 1-2 (81,5 \% проти 19,2 \%, $\mathrm{p}<0,01)$

Висновки. ХГС у хворих із фіброзом печінки F 3-4 характеризується частішою появою змішаних кріоглобулінів, вищим вмістом RF-IgM і ЦІК у сироватці крові, ніж у пацієнтів із фіброзом печінки F 1-2. Це пояснює більшу частоту клінічної маніфестації позапечінкових проявів імунокомплексного генезу в пацієнтів із фіброзом печінки $\mathrm{F} 3-4$. Гістологічна активність АЗ у хворих на ХГС найчастіше поєднується з фіброзом печінки $F$ 3-4, що зумовлює високу частоту розвитку кріоглобулінемічного васкуліту в цих хворих.
Key words: chronic hepatitis $\mathrm{C}$ immunohistochemistry, extrahepatic manifestations.

Pathologia 2018; 15 (1), 45-48 DOI: 10.14739/2310-1237. 2018.1.129194

\section{E-mail:}

RyabokonZSMU@ gmail.com
Ключові слова: хронічний гепатит C, імуногістохімія, позапечінкові прояви.

Патологія. - 2018. T. 15, № 1(42). C. $45-48$

\section{Взаимосвязи морфологических изменений в печени с развитием внепеченочных проявлений у больных хроническим гепатитом C}

\section{Ю. Ю. Рябоконь, В. А. Туманский, Е. В. Рябоконь}

Цель работы - проанализировать взаимосвязи морфологических изменений в печени с манифестацией клинических 
Патология. - 2018. T. 15, № 1(42). C. $45-48$

Материалы и методы. В исследование включены 86 больных ХГС. Проведен анализ взаимосвязей степени выраженности фиброза печени и гистологической активности в зависимости от наличия клинических признаков внепеченочных проявлений заболевания и изменений аутоиммунных параметров.

Результаты. Установлено, что частота появления смешанных криоглобулинов в крови больных ХГС имела зависимость от степени фиброза печени. При наличии фриброза печени F 3-4 смешанные криоглобулины определены у 94,2 \% против 64,7 \% больных со стадиями фиброза печени F 1-2 ( $<$ 0,01). У больных со стадиями фиброза печени F 3-4 количественное содержание смешанных криоглобулинов, RF-IgM и ЦИк было выше аналогичных показателей больных со стадиями фиброза печени F 1-2. У пациентов с фиброзом печени F 3-4 частота обнаружения криоглобулинемического васкулита с формированием триады Мельтцера была выше, чем у пациентов с фиброзом печени F 1-2 $(19,2 \%$ против 2,9\%, p < 0,05). Содержание смешанных криоглобулинов коррелировало со степенью выраженности фиброза печени ( $r=+0,49, p<0,01)$. Активность АЗ чаще установлена у больных со стадиями фибброза печени $\mathrm{F} 3-4$ по сравнению с пациентами со стадиями фриброза F 1-2 (81,5 \% против 19,2%, p < 0,01).

Выводы. ХГС у больных с фиброзом печени F 3-4 характеризуется более частым появлением смешанных криоглобулинов, более высоким содержанием RF-IgM и ЦИК в крови, чем у пациентов с фиброзом печени F 1-2. Это объясняет более высокую частоту клинической манифестации внепеченочных проявлений иммунокомплексного характера у больных с фиброзом печени F 3-4. Гистологическая активность АЗ у больных ХГС наиболее часто сочетается с фиброзом печени F 3-4, что обусловливает высокую частоту развития криоглобулинемического васкулита у этих пациентов.

Chronic Hepatitis $\mathrm{C}(\mathrm{CHC})$ is characterized not only by the high risk of progression of liver fibrosis with the formation of liver cirrhosis and hepatocellular carcinoma, but also a high incidence of extrahepatic manifestations that increase the risk of mortality in these patients [1-3]. The presence of features of liver damage in patients with the presence of extrahepatic manifestations is a controversial issue. In the first studies there was a hypothesis about the superiority of less pronounced liver damage in patients with $\mathrm{CHC}$ with mixed cryoglobulinemia, because the prevention of hepatocyte infection was explained by the possible blockade of receptors to very low density lipoproteins, through which HCV enters the liver cells by endocytosis by monoclonal lgM-k with activity of rheumatoid factor (RF) [4]. It is believed that $\mathrm{HCV}$ replicated in the cells of the immune system causes chronic stimulation, which creates conditions for poly- and monoclonal proliferation of B-lymphocytes, poly- and monoclonal production of IgM-RF, which is the basis of mixed cryoglobulins. HCV-infection is characterized by the unique immunological phenomenon: no other infection is noted with such a high frequency of RF production and its specificity $[5,6]$. In the research [7] on the contrary, it was shown that in the significant number of patients with $\mathrm{HCV}$-infection mixed cryoglobulinemia was characterized by a distinct advantage of fibrosis with cirrhosis. According to the authors [8], it is IgM-RF in any living thing as the progression of liver fibrosis by stimulating Kupffer cells to synthesize paracrine compounds that accelerate the synthesis of extracellular matrix proteins.

\section{The purpose of the work}

To analyze the relationships of morphological changes in the liver with the manifestation of clinical signs of extrahepatic manifestations in patients with chronic hepatitis $\mathrm{C}$.

\section{Material and methods}

The study included 86 patients of the hepatological centre of Zaporizhzhia Regional Infectious Clinical Hospital. The stage of liver fibrosis and histological activity were determined on the METAVIR scale in the morphological study of hepatobiopsy (conducted in the University Hos- pital of ZSMU, MD, PhD, DSc, prof. V. A. Tumanskiy) or through noninvasive Fibrotest and Actitest. The age of the patients ranged from 18 to 60 years, there were 34 men, 52 women. Patients were divided into groups: 34 patients with stages $F 1-2$ and 52 patients with stages F 3-4 liver fibrosis. Histological Activity A1 was in 31 patients, A2 - 28 patients, $A 3$ - in 27 patients.

Specific research methods included determination of the content of RF-IgM and RF-IgG in serum (ORGENTEC, Germany); circulating immune complexes (CIC) (Hycult biotech, USA) by the immunoassay method and the content of mixed cryoglobulins by spectrophotometric method. The control group included 30 healthy people. All the special researches were carried out in the Educational Medical and Laboratory Center of ZSMU (Head - MD, $\mathrm{PhD}$, DSc, prof. A. V. Abramov).

Statistical analysis of the results was performed using the existing database of surveyed patients and healthy individuals in the program Statistica ${ }^{\circledR}$ for Windows 6.0 (StatSoft Inc., №AXXR712D833214FAN5). The research results are presented as $\mathrm{Me}\left(Q_{25} ; Q_{75}\right)$. When evaluating the significance of quantitative features differences between samples Mann-Whitney criterion was used, qualitative characteristics - method of chi-square $\left(X^{2}\right)$. The degree of connection between the signs was estimated by the Spearman's rank correlation method.

\section{Research results and their discussion}

According to the results of the research, it was established that biochemical signs of mixed cryoglobulinemia were detected in 71 (82.5\%) patients with $\mathrm{CHC}$, and the frequency of their appearance was dependent on the degree of liver fibrosis. In the presence of liver fibrosis F 3-4 mixed cryoglobulins were detected in $49(94.2 \%)$ patients versus $22(64.7 \%)$ patients with liver fibrosis stages $F$ $1-2\left(X^{2}=12.4 ; P<0.01\right)$ This regularity was confirmed by the results of the comparison of the quantitative content of blood serum as mixed cryoglobulins and the content of $\mathrm{RF}$ and $\mathrm{ClC}$. In patients with $\mathrm{CHC}$ liver fibrosis stages $\mathrm{F}$ 3-4 cryoglobulins mixed content, RF-IgM and $\mathrm{CIC}$ were significantly higher than similar rates in patients with liver fibrosis F 1-2 (Table 1).

The increase in the frequency of detection of mixed 
cryoglobulins, the level of increase in their content, as well as the content of RF-IgM and CIC in serum in patients with $\mathrm{CHC}$ in the progression of liver fibrosis were associated with clinical manifestations of cryoglobulinemia syndrome. Thus, in patients with stages of liver fibrosis F 3-4, the frequency of detection of hemorrhagic cryoglobulinemic vasculitis with the formation of Meltzer's triad was higher than in patients with stages of liver fibrosis F 1-2 (19.2\% versus $\left.2.9 \%, X^{2}=4.90 ; P<0.05\right)$. The positive correlation between the average level of the quantitative content of mixed cryoglobulins in the serum and the degree of expressiveness of the liver fibrosis $(r=+0.49$; $P<0.01)$ confirms the pattern found in our study. Analysis of other extrahepatic manifestations showed no statistically significant difference in the frequency of their detection $(\mathrm{P}>0.05)$ in patients with $\mathrm{CHC}$ with different stages of liver fibrosis. However, isolated extrahepatic manifestations, namely, porphyria cutanea tarda, B-cell non-Hodgkin's lymphoma, were registered in rare cases only in patients with stage F 3-4 liver fibrosis (Table 2).

As a result of comparing the severity of liver fibrosis and histological activity, it was noted that high activity of A3 was more common in patients with stages of $F$ 3-4 fibrosis compared to patients with stage of fibrosis $F$ 1-2 $\left(81.5 \%\right.$ vs. $\left.19.2 \%, X^{2}=6.42 ; P<0.01\right)$. In this case, in the presence of histological activity of both $A 2$ and $A 1$, fibrosis of the liver F 1-2 and F 3-4 were recorded with the same frequency. The revealed pattern was confirmed by a positive correlation between the average degree of the stage of liver fibrosis and the degree of histological activity $(r=+0.36, P<0.05)$. Further analysis showed that in the presence of high histological activity $A 3$ the frequency of detection of hemorrhagic cryoglobulinemic vasculitis and Meltzer's triads was superior in comparison to patients with histologic activity A1 (22.2\% vs. $3.2 \%$, $\left.X^{2}=4,90 ; P<0.05\right)$.

The patterns found in our study indicate a significant role of the progression of the degree of liver damage in the manifestation of extrahepatic manifestations of immunocomplex genesis, primarily cryoglobulinema syndrome. The idea that mixed cryoglobulinemia is a valuable prognostic indicator of the increased risk of progression of $\mathrm{CHC}$ in liver cirrhosis is confirmed by the presence of a higher degree of liver fibrosis on the METAVIR scale in patients with $\mathrm{CHC}$ with mixed cryoglobulinemia, in contrast to patients without this manifestation, for the same average indexes of histological activity of the process [9]. In the development of cryoglobulinema syndrome at the stage of liver cirrhosis the disruption of the function of removal of immune complexes, in particular, mixed cryoglobulins, by the reticuloendothelial system plays a role [10]. In modern literature, the discussion of the features of pathogenetic mechanisms of liver damage in patients with $\mathrm{CHC}$ with mixed cryoglobulinemia is continued. It is believed that the $\mathrm{CIC}$, which contains mixed cryoglobulins, is capable of binding to C1q-receptors on endothelial cells of blood vessels due to HCV core-proteine or bound to RF-IgM C1q-complex. The postponement of CIC in the blood vessels of the liver, activation of the complement system and the response of liver cells to inflammatory mediators lead to the formation of alterative-proliferative lesions of arteries of portal tracts [11]. According to [12], in patients
Table 1. Comparison of the quantitative content of mixed cryoglobulins, RF $\operatorname{lgM} / \lg G$ and $\mathrm{CIC}$ in patients with $\mathrm{CHC}$ with different stages of liver fibrosis, $\mathrm{Me}\left(\mathrm{Q}_{25} ; \mathrm{Q}_{75}\right)$

\begin{tabular}{l|l|l|l|}
\multirow{2}{*}{ Indicator } & \multirow{2}{*}{$\begin{array}{l}\text { Healthy people } \\
(\mathbf{n}=\mathbf{3 0})\end{array}$} & \multicolumn{3}{|l|}{ Patients with $\mathbf{C H C}(\mathbf{n}=\mathbf{8 6})$} \\
\cline { 3 - 4 } & & $\mathbf{F} \mathbf{1 - 2}(\mathbf{n}=\mathbf{3 4})$ & $\mathbf{F} \mathbf{3 - 4}(\mathbf{n}=\mathbf{5 2})$ \\
\hline Mixed cryoglobulins, opt. & $<2.50$ & $3.45(2.19 ; 4.30)$ & $4.23(3.90 ; 4.85) .$. \\
\hline RF-IgM, IU/ml & $<20$ & $56.9(19.9 ; 112.3)$ & $104.8(34.8 ; 202.0) .$. \\
\hline RF-IgG, IU/ml & $<20$ & $60.4(29.6 ; 129.4)$ & $78.5(57.1 ; 114.2)$ \\
CIC, mAU/ml & $184.8(156.8 ; 197.3)$ & $226.7(201.2 ; 268.7)$ & $535.0(448.3 ; 865.6) *$ *** \\
\hline
\end{tabular}

*: the difference is significant, compared with healthy people $(P<0.05)$; **: compared with patients with $\mathrm{CHC}$ liver fibrosis F 1-2 $(\mathrm{P}<0.05)$.

Table 2. Comparison of the frequency of detection of clinical signs of extrahepatic manifestations of $\mathrm{CHC}$ in patients depending on the stage of liver fibrosis, abs (\%)

\begin{tabular}{l|ll|}
\hline \multirow{2}{*}{ Criterion } & \multicolumn{2}{|l}{$\begin{array}{l}\text { Patients with CHC } \\
\text { with stages of fibrosis of the liver }\end{array}$} \\
\cline { 2 - 3 } & $\mathbf{F}$ 1-2 (n= 34) & F 3-4 (n = 52) \\
\hline Clinical signs of cryoglobulinemia syndrome & & \\
\hline Expression of general weakness & $27(79.4 \%)$ & $48(92.3 \%)$ \\
\hline Arthralgia & $14(41.2 \%)$ & $27(51.9 \%)$ \\
\hline Hemorrhagic cryoglobulinemic vasculitis & $1(2.9 \%)$ & $10(19.2 \%)^{\circ}$ \\
\hline Meltzer's Triad & $1(2.9 \%)$ & $10(19.2 \%)^{*}$ \\
\hline Kidney damage & $1(2.9 \%)$ & $1(1.9 \%)$ \\
\hline Other extrahepatic manifestations & & \\
\hline Lesion of the thyroid gland & $15(44.1 \%)$ & $29(55.8 \%)$ \\
\hline Diabetes mellitus 2 & $1(2.9 \%)$ & $3(5.8 \%)$ \\
\hline Dry syndrome & $4(11.8 \%)$ & $13(25.0 \%)$ \\
\hline Lichen planus & $1(2.9 \%)$ & $1(1.9 \%)$ \\
\hline Peripheral sensory polyneuropathy & $1(2.9 \%)$ & $2(3.8 \%)$ \\
\hline Porphyria cutanea tarda & - & $1(1.9 \%)$ \\
\hline B-cell non-Hodgkin's lymphoma & - & $1(1.9 \%)$ \\
\hline
\end{tabular}

*: the difference is significant $(P<0.05)$ compared with patients with stages of liver fibrosis $F 1-2$.

with $\mathrm{CHC}$ with mixed cryoglobulinemia, unlike patients without this manifestation, changes in small branches of a. hepatica are more often detected in the form of proliferation of smooth muscle cells ( $30.2 \%$ vs. $3.3 \%, \mathrm{P}<0.05)$, preferably in the presence of severe liver fibrosis. In addition, only patients with $\mathrm{CHC}$ with mixed cryoglobulinemia (15.9\%) showed increased lymphoid follicles in portal tracts. The expressiveness of morphological changes in the liver of patients with HCV-associated mixed cryoglobulinemia did not depend on the age, sex of patients and duration of the disease [12]. The aforementioned data of modern literature and the patterns found in our study, in our opinion, allow us to discuss faster rates of progression of liver fibrosis in patients with $\mathrm{CHC}$ in the presence of mixed cryoglobulinemia.

According to the authors [13] lower effectiveness of antiviral treatment using regimens containing interferon for $\mathrm{CHC}$ patients with mixed cryoglobulinemia is due to the heavier necrosis-inflammatory process in the liver and higher RF content. Recently, antiviral drugs with a direct mechanism of action have appeared, which have a higher efficiency and a high safety profile. It allowed treating patients with $\mathrm{CHC}$, including mixed cryoglobulinemia, without interferon. In 2015, European Association for the Study of the Liver clinical protocols recommended to conduct antiviral treatment of $\mathrm{CHC}$ with extrahepatic manifestations of priority regardless of the degree of liver fibrosis (level of evidence A1) [14]. 


\section{Conclusions}

1. $\mathrm{CHC}$ in patients with stages of liver fibrosis $\mathrm{F}$ 3-4 is characterized by a more frequent appearance of mixed cryoglobulins in blood serum $(94.2 \%$ vs. $64.7 \%$, $\mathrm{P}<0.01$ ), their higher quantitative content, and higher content of RF-IgM and $\mathrm{ClC}$ in serum than in patients with liver fibrosis stages $F$ 1-2 $(P<0.05)$. The revealed pattern explains a higher frequency a clinical manifestation of extrahepatic manifestations of immunocomplex genesis in patients with $\mathrm{F} \mathrm{3-4}$ fibrosis, namely the development of the hemorrhagic cryoglobulinemic vasculitis with the formation of the Meltzer's triad $(19.2 \%$ vs. $2.9 \%, P<0.05)$ than in patients with stages of liver fibrosis $F$ 1-2.

2. Histological activity of $A 3$ in patients with $\mathrm{CHC}$ is most often combined with stages of liver fibrosis $\mathrm{F}$ 3-4 $(81.5 \%)$, which causes more frequent occurrence of hemorrhagic cryoglobulinemic vasculitis in patients with histological activity of $\mathrm{A} 3$, compared to A1 activity (22.2\% vs. $3.2 \%, P<0.05)$.

3. The incidence of extrahepatic manifestations not related to mixed cryoglobulinemia does not depend on the degree of expressiveness of the morphological changes in the liver, but some extrahepatic manifestations (porphyria cutanea tarda, B-cell non-Hodgkin's lymphoma) are registered in rare cases only in patients with fibrosis F 3-4.

Prospects for further research, in our opinion, the development of methods for early diagnosis of extrahepatic manifestations of $\mathrm{CHC}$ should be included for further individualization of treatment of these patients.

Conflicts of Interest: authors have no conflict of interest to declare. Конфмікт інтересів: віАсутній.

Information about authors:

Riabokon Yu. Yu., MD, PhD, DSc, Associate Professor of the Department of Children Infectious Diseases, Zaporizhzhia State Medical University, Ukraine.

Tumanskiy V. A., MD, PhD, DSc, Professor of the Department of Pathologic Anatomy and Forensic Medicine, Zaporizhzhia State Medical University, Director of Human Clinical Pathology Institute, Honorary Scientist and Engineering Worker of Ukraine.

Riabokon E. V., MD, PhD, DSc, Professor, Head of the Department of Infectious Diseases, Zaporizhzhia State Medical University, Ukraine.

\section{Відомості про авторів:}

Рябоконь Ю. Ю., А-р меА. наук, Аоцент каф. Аитячих інфекційних хвороб, Запорізький державний медичний університет, україна.

Туманський В. О., А-р меА. наук, професор каф. патологічної анатомії та судової медицини, Запорізький Аержавний медичний університет, Аиректор Інституту клінічної патології ^юдини, заслужений Аіяч науки і техніки України.

Рябоконь О. В., А-р меА. наук, професор, зав. каф. інфекційних хвороб, Запорізький державний медичний університет, Україна.

\section{Сведения об авторах:}

Рябоконь Ю. Ю., А-р меА. наук, Аоцент каф. Аетских инфекционных болезней, Запорожский государственный медицинский университет, Украина.

Туманский В. А., А-р меА. наук, профессор каф. патологической анатомии и судебной медицины, Запорожский государственный меАицинский университет, Аиректор Института клинической патологии человека, заслуженный Аеятель науки и техники Украины.
Рябоконь Е. В., А-р меА. наук, профессор, зав. каф. инфекционных болезней, Запорожский государственный медицинский университет, Украина.

Надійшла Ао редакції / Received: 29.03.2018

Після Аоопрацювання / Revised: 04.04.2018

Прийнято Ао Аруку / Accepted: 06.04.2018

\section{References}

[1] Negro, F., Forton, D., Craxì, A., Sulkowski, M., Feld, J. J., \& Manns, M. P. (2015) Extrahepatic Morbidity and Mortality of Chronic Hepatitis C. Gastroenterology, 149(6), 1345-1360. doi: 10.1053/j. gastro.2015.08.035

[2] Roccatello, D., Sciascia, S., Rossi, D., Solfietti, L., Fenoglio, R., Menegatti, E., \& Baldovino, S. (2017) The challenge of treating hepatitis $C$ virus-associated cryoglobulinemic vasculitis in the era of anti-CD20 monoclonal antibodies and direct antiviral agents. Oncotarget, 8(25) 41764-41777. doi: 10.18632/oncotarget.16986.

[3] Allison, R. D., Tong, X., Moorman, A. C., Ly, K. N., Rupp, L., Xu, F., et al. (2015) Increased incidence of cancer and cancer-related mortality among persons with chronic hepatitis C infection, 2006-2010. Journal of Hepatology, 63(4), 822-828. doi: 10.1016/j.jhep.2015.04.021.

[4] Agnello, A. (1997) Hepatitis C virus infection and type II cryoglobulinemia: an immunological perspective. Journal of Hepatology, 26(6), 1375-1379. doi: 10.1053/jhep.1997.v26.ajhep0261375.

[5] Yang, D. H., Ho, L. J., \& Lai, J. H. (2014) Useful biomarkers for assessment of hepatitis $C$ virus infectious-associated autoimmune disorders World Journal Gastroenterology, 20(11), 2962-2970. doi: 10.3748/ wjg.v20.i11.2962.

[6] Cacoub, P., Comarmond, C., Domont, F., Savey, L., Desbois, A. C. \& Saadoun, D. (2016) Extrahepatic manifestation of chronic hepatitis virus infection. Therapeutic Advances in Infectious Disease, 3(1), 3-14. doi: $10.1177 / 2049936115585942$.

[7] Milovanova, S. Yu., Kozlovskaya, L. V., \& Gordovskaya, N. B. (2014) Polimorfizm klinicheskikh proyavlenij krioglobulinemicheskogo vaskulita, associirovannogo s khronicheskim gepatitom C [Polymorphism of clinical manifestations of cryoglobulinemia-related vasculitis associated with chronic hepatitis $\mathrm{C}$ virus infection]. Al'manakh klinicheskoj mediciny, 30, 46-51. [in Russian].

[8] Atta, A. M., Oliveira, I. S., Sousa, G. M., Paraná, R., \& Atta, M. L. (2010) Serum cytokine profile in hepatitis $C$ virus carriers presenting cryoglobulinaemia and nonorgan-specific autoantibodics. Microbial Pathogenesis, 48, 53-56. doi: 10.1016/j.micpath.2009.12.002.

[9] Saadoun, D., Asselah, T., Resche-Rigon, M., Charlotte, F., Bedossa, P., Valla, D., et al. (2006) Cryoglobulinemia is associated with steatosis and fibrosis in chronic hepatitis C. Journal of Hepatology, 43(6), 1337-1345. doi: 10.1002/hep.21190.

[10] Andrade, L. J., Santana de Melo, P. R., Atta, A. M., Atta, M. L., Jesus, L. S., Sousa, G. M., et al. (2011) Smooth muscle antibodies and cryoglobulinemia are associated with advanced liver fibrosis in Brazilian hepatitis C virus carriers. Brazilian Journal of Infectious Diseases, 15(1), 66-8. doi: 10.1016/S1413-8670(11)70142-8.

[11] Dunaeva, N. V., Karev, V. E., Vorobyeva, O. A., Mazing, A. V., Lapin, S. V., Smirnov, A. V., \& Gusev, D. A. (2016) Protivovirusnaya terapiya khronicheskogo gepatita C, oslozhnennogo sistemnym krioglobulinemicheskim vaskulitom [Antiviral therapy of chronic hepatitis $\mathrm{C}$, complicated by systemic cryoglobulinemic vasculitis]. Zhurnal infektologii, 8(2), 40-47. [in Russian].

[12] Milovanova, S. Yu. (2013) Smeshannaya krioglobulinemiya, associirovannaya s khronicheskim gepatitom C: znachenie v razvitil vnepechenochnykh poyavleniy, metody lecheniya (Avtoref. dis... dokt. med. nauk) [Mixed cryoglobulinemia associated with chronic hepatitis $\mathrm{C}$ : significance in the development of extrahepatic events, methods of treatment. Dr. med. sci. diss.]. Moscow. [in Russian]

[13] Gragnani, L., Visentini, M., Fognani, E., Urraro, T., De Santis, A., Petraccia, L., et al. (2016) Prospective study of guideline-tailored therapy with direct-acting antivirals for hepatitis c virusassociated mixed cryoglobulinemia. Journal of Hepatology, 64(5), 1473-1482. doi: $10.1002 /$ hep. 28753 .

[14] European Association for the Study of the Liver. (2015) EASL Recommendations on Treatment of Hepatitis C 2015. Journal of Hepatology 63(1), 199-236. doi: 10.1016/j.jhep.2015.03.025. 